\title{
Process Research on the Establishment of "Market" Concept in Chinese State-owned Enterprises Reform
}

\author{
Chunyu Li \\ School of Management and Economics, Beijing Institute of Technology, Beijing, 102488, China
}

Keywords: State-owned enterprises reform, Market economy, Marketization

\begin{abstract}
The reform of the state-owned enterprises is the central link in the economic reform of China. The reform of state-owned enterprises experienced two stages, which are delegating powers and benefits and divergence between control rights and cash-flow rights. At present, China has entered into the stage of establishing a modern enterprise system and strategic adjustment. In the process of marketization, meanwhile, a lot of difficult problems appear. In this paper, a large number of documents are used to analyze the cases of marketization reform of state-owned enterprises and the ways of dealing with them in other countries to explore the process of marketization and market concept.
\end{abstract}

\section{Necessity of State-owned Enterprises Reform from the Perspective of Market Mechanism}

\subsection{Market Mechanism and Planned Mechanism}

Market mechanism refers to the way of distribution of resources through market competition. The resources in the market achieve the flow through competition and exchange and achieve a reasonable allocation through the law of price. In the market mechanism, the market plays a decisive role, and the role of the government is to decentralization and support. The plan mechanism refers to the government's introduction of indicators, all the allocation of resources follows the state instructions, the state unified production and scheduling. However, because the government's prediction of the economy can't reflect the real situation, if it is not done in time and correctly, there will be a problem of insufficient budgets and insufficient production, leading to economic stagnation. A fatal flaw in the planning mechanism is that it does not have a sound incentive mechanism like the market mechanism, which leads to a decline in efficiency.

\subsection{A Review of State-owned Enterprises Reforms to Date}

The state-owned enterprises in our country first experienced the link of delegating powers and benefits. After the third Plenary Session of the 11th CPC Central Committee, our country initially emancipated the ideology and recognized the market mechanism and the law of price in theory. The administrative departments of the government began to liberalize some of their rights and expand their business autonomy, which has made considerable achievements.

From 1985 to 1993, the reform of state-owned enterprises in China came to the stage of separation of the two powers. In the third Plenary Session of the 12th CPC Central Committee, it was proposed to establish a planned system of conscious use of the law of value. The state-owned enterprises should pursue independent operation and take their own profits and losses. This step gives the planned economy a formal approach to the market mechanism. After the success of the rural household contract responsibility system, the government began to implement the contract system and the lease system in a large scale. The state enterprises began to separate from government and administrative departments, which promoted the separation of government and enterprise responsibilities. The government has set up the enterprise law to implement the independent production and operation rights of the state-owned enterprises.

Inspired by Comrade Deng Xiaoping's speech, the reform of China's state-owned enterprises has 
been gradually strengthened. It is now in the stage of the establishment of the modern enterprise system and the strategic adjustment of the state economy. China's state-owned enterprises have gradually begun to form the competitive mechanism of the fittest, rather than to reduce the efficiency of low efficiency enterprises to reduce the economic effect. The state chooses the form of reform and the concrete reform plan in a reasonable way through the pilot. The state assets commission has been set up to manage state-owned assets. Under the leadership of the SASAC, China has taken a preliminary step towards the separation of government and enterprise. At the same time, the government has continuously expanded the number of large state-owned enterprises to carry out pilot reform, including ten largest military industrial groups, resources companies and communications companies.

\subsection{Problems to be Solved for Further Marketization}

From 1990s, the reform of mixed ownership began to prevail. Although the version of the reform program is different, it was characterized by allowing domestic private capital and foreign investment to participate in the reform of state-owned enterprises. It helped to improve the productivity of the state-owned enterprises, and the practical experience also proved it.

Although many state-owned enterprises have reduced the proportion of state capital, the reorganization of state-owned assets structure has not completely restricted the government's intervention in state-owned enterprises. In fact, the government's intervention in state-owned enterprises is still everywhere. To further reform the market, we must open the price control. In the process of transformation from planned economy to market economy, our country has implemented a two-track policy for price liberalization, that is, there are both intra institutional and extra institutional prices. With the expansion of the price outside the system, the price of the system is withdrawn from the market, and the transition to the price monorail system and the change of the market economy are realized. At that time, the government implemented an incremental reform to encourage the development of enterprises and enterprises, and temporarily laid down the complex reform of state-owned enterprises. The author believes this idea can also be used to solve the problem that some state-owned enterprises are monopolized so that the price cannot be liberalized.

In addition to the pursuit of economic effects, the state-owned enterprises have also undertaken a lot of social responsibility. For example, medical care, pension, and employment rate, hire more employees than demand, housing problems, education problems, narrow the gap between the rich and the poor and so on. When the government is unable to establish a perfect public medical system, the state-owned hospitals need to replace the government to subsidize the low-income medical groups. For example, when the country needs to rectify the inflation problem, the government often stipulates that the prices of many monopoly enterprises cannot rise, even if they are in short supply. The marketization needs the present state-owned enterprises to change from the dual goals of pursuing interests and social responsibilities into a single goal of pursuing interests. This makes it possible for us to do a good job in the integration before it is marketed.

To sum up, we can see that the state-owned enterprise reforms are all moving towards non-state-owned enterprises. Now the problems faced by state-owned enterprises can be solved through further market-oriented reform. Therefore, we can preliminarily think that the marketization is the only way to further the reform of state-owned enterprises. For the further reform of state-owned enterprises, the author puts forward some suggestions: first, we must establish the state-owned assets before the hybrid propulsion system reform evaluation standard and the transfer of supervision system; second, in terms of price, the government should first classify state-owned enterprises, price liberalization prior to encourage private enterprises to form development for state-owned enterprises in the competitive environment; third, before discharging from the social responsibility of the state-owned enterprises, we must first establish the relevant agencies for docking to prevent the situation that nobody shoulder the social responsibility; fourth, to improve the structure of Chinese legal system to regulate the responsibility of the government and to supervise the macroeconomic

macro market to support the marketization and opening to the outside world of the state-owned enterprises; fifth, to regulate the financial system, remove unfair preference to state-owned 
enterprises, and develop the bond market to ease bank pressure. At the same time, to unify the prices of the different markets so that the price mechanism can work. In this process, the government plays a great role.

\section{Marketization Benefit Survey of Tongrentang and SAIC}

Both Tongrentang and SAIC are the key objects of the reform of the state-owned enterprises and the pilot enterprises of the market. Therefore, in this chapter, the author investigates the market history of the two enterprises and analyzes the financial figures of the enterprises in recent years, and summarizes the benefits brought by the marketization.

\subsection{Marketization Process of Tongrentang}

Tongrentang is moving towards the market step by step. From the Qing Dynasty, Tongrentang has continuously deepened the new market by the leading enterprises of science and technology. As the key company of the reform of the state-owned enterprises, Tongrentang has experienced the reform of the mixed ownership system of the company's stock system. Tongrentang has a perfect management team, which makes the operating income of Tongren Tang increase year by year. In addition to the constant research and development and the original reputation of the Tongrentang, it can be said that the Tongrentang has the ability to continue to make money.

Conclusion: In the process of listing, Tongrentang adapted to market competition through its analysis of market and pursuit of innovation. It was successfully chosen by market to achieve business continuity and responsibility for the state.

Table 1. Indexes of operation ability of Tongrentang

\begin{tabular}{|c|c|c|c|c|c|c|}
\hline Year & 2010 & 2011 & 2012 & 2013 & 2014 & 2015 \\
\hline $\begin{array}{c}\text { Total asset } \\
\text { running rate }\end{array}$ & 0.73 & 0.95 & 0.88 & 0.81 & 0.78 & 0.79 \\
\hline $\begin{array}{c}\text { Receivable } \\
\text { turnover in days }\end{array}$ & 27.6 & 17.19 & 14.81 & 16.38 & 20.37 & 24.8 \\
\hline $\begin{array}{c}\text { Inventory } \\
\text { turnover in days }\end{array}$ & 333.12 & 260.46 & 292.81 & 284.18 & 286.98 & 297.57 \\
\hline
\end{tabular}

Table 2. Indexes of development ability of Tongrentang

\begin{tabular}{|c|c|c|c|c|}
\hline Index of Development Ability & 2012 & 2013 & 2014 & 2015 \\
\hline Gross revenue (billion Yuan) & 7.52 & 8.71 & 9.69 & 10.8 \\
\hline Gross profit(billion Yuan) & 3.22 & 3.65 & 4.08 & 4.87 \\
\hline Net income attributed to shareholders(billion Yuan) & 0.57 & 0.656 & 0.764 & 0.875 \\
\hline $\begin{array}{l}\text { Net profit after extraordinary gains and losses (billion } \\
\text { Yuan) }\end{array}$ & 0.554 & 0.633 & 0.746 & 0.868 \\
\hline Year-on-year growth of gross revenue(\%) & 22.85 & 15.94 & 11.14 & 11.59 \\
\hline $\begin{array}{r}\text { Year-on-year growth of net income attributed to } \\
\text { shareholders(\%) }\end{array}$ & 30.13 & 15.08 & 16.41 & 14.6 \\
\hline $\begin{array}{l}\text { Year-on-year growth of net profit after extraordinary } \\
\text { gains and losses (\%) }\end{array}$ & 35.45 & 14.42 & 17.73 & 16.44 \\
\hline Rolling cycle growth of gross revenue(\%) & 4.91 & 4.3 & 4.36 & 3.45 \\
\hline $\begin{array}{l}\text { Rolling cycle growth of net income attributed to } \\
\text { shareholders(\%) }\end{array}$ & 7.44 & 2.54 & 4.9 & 3.32 \\
\hline $\begin{array}{l}\text { Rolling cycle growth of net profit after extraordinary } \\
\text { gains and losses(\%) }\end{array}$ & 11.4 & 2.63 & 5.28 & 3.9 \\
\hline
\end{tabular}


Table 3. Taxes payable of Tongrentang

\begin{tabular}{|c|c|c|c|c|}
\hline & 2011 & 2012 & 2013 & 2014 \\
\hline Taxex payable & 48052836 & 109853875 & 126391922 & $1950,530,93$ \\
\hline
\end{tabular}

Note: Table 1, table2 and table 3 are all quoted from annual report of Tongrentang.

\subsection{Marketization Process of SAIC.}

SAIC Group is a listed stock company of state-owned shares holding. Since 1978, SAIC has seized the opportunity of reform and opening and accelerated its development using foreign capital and the introduction of technology. As a manufacturing industry SAIC Group has opened a new market through its own production and joint venture. Although SAIC actively reflected the stock and successfully listed, its share of state-owned funds has not been greatly affected, and it remained at 71.64\% until 2017.

Table 4. Financial reports of SAIC Group

\begin{tabular}{|l|l|l|l|l|l|}
\hline & 2010 & 2011 & 2012 & 2013 & 2014 \\
\hline Total assets & 285,045 & 318,633 & 317,203 & 373,641 & 414,871 \\
\hline Total liabilities & 171,532 & 185,517 & 172,197 & 211,909 & 229,872 \\
\hline Total liquid assets & 175,947 & 191,233 & 189,155 & 232,184 & 237,043 \\
\hline Total liquid liabilities & 148,932 & 162,513 & 156,352 & 184,865 & 199,932 \\
\hline Liquidity & 1.18 & 1.18 & 1.21 & 1.26 & 1.19 \\
\hline
\end{tabular}

Table 5. Profit table of SAIC Group

\begin{tabular}{|l|l|l|l|l|l|}
\hline & 2010 & 2011 & 2012 & 2013 & 2014 \\
\hline Gross revenue & 365,724 & 434,804 & 480,980 & 565,807 & 630,001 \\
\hline Grosss cost & 343,444 & 406,247 & 401,188 & 491,712 & 550,146 \\
\hline Annual profit & 22,280 & 28,557 & 79,792 & 74,095 & 79,855 \\
\hline Profit margin & $6 \%$ & $7 \%$ & $17 \%$ & $13 \%$ & $13 \%$ \\
\hline Business tax and additional tax & 8,434 & 11,054 & 7,975 & 3,439 & 3,757 \\
\hline
\end{tabular}

Table 6. Social responsibility report of SAIC Group

\begin{tabular}{|l|l|l|l|}
\hline & 2014 & 2015 & 2016 \\
\hline Total investment of environmental protection(million Yuan) & 196 & 223 & 222 \\
\hline Investment of energy conservation(million Yuan) & 5 & 9 & 19 \\
\hline Volume reduction of single car waste(kilograms per car) & 9.3 & 1.6 & 1.3 \\
\hline Energy saving of output value(tons of standard coal) & 7,332 & 65,335 & 46,720 \\
\hline Total donation(million Yuan) & 5.67 & 6.63 & 7.87 \\
\hline Total participation person-times of volunteer activities & 1,971 & 2,629 & 2,910 \\
\hline Total time of volunteer activities(hours) & 7,388 & 9,628 & 10,438 \\
\hline Times of volunteer activities & 161 & 232 & 300 \\
\hline
\end{tabular}

Conclusion: in the process of marketization, the profit rate of SAIC Group has been slightly reduced in recent years, but it has basically adapted to the market competition and has the sustainability. It is also responsible for the environment and society beyond the tax. 


\section{Conclusions}

Through quantitative analysis and enterprise case support, this paper preliminarily proves that the in-depth marketization is the direction for further reform of state-owned enterprises. Through the summary and analysis of the history of the reform of state-owned enterprises, we can find that the history of the reform of the state-owned enterprises is the process of introducing the market mechanism. The market mechanism under socialism is the system that should be pursued.

Tongrentang and SAIC Group are the pioneers in the reform of the two state-owned enterprises. The article briefly presents the concrete process of marketization in the enterprise and the impact on the economic benefits of the market. In addition, it also hopes to show how the state-owned enterprises continue to bear social responsibility and serve the people through the two enterprises.

The government's impact on state-owned enterprises is far-reaching. If we want to further succeed in the reform of state-owned enterprises, the government should not only take the responsibility of directing reform to introduce policies and laws, but also recognize the role of itself to avoid excessive intervention of state-owned enterprises.

\section{References}

[1] Xu Zhaoyuan, Zhang Wenkui. SOEs Reform's Impact on Economc Growth [J]. Economic Research Journal, 2015(4): 122-135.

[2] Zhang Xin. The Crux of Chinese State-owned Enterprises Reform-An Analysis Under the Framework of Karl Marx's Das Kapital [J]. Finance and Trade Research, 2014(7): 11-21.

[3] Zhang Bingshi, Ma Zhong, Xia Zihang. Theoretical Research on the Mixed Ownership Reform in State -Owned Enterprises [J]. Reform of Economic System, 2017(6): 5-11.

[4] Yu Jing, Huang Qunhui. Deepening the Reform of State-owned Enterprises in the New Era: Progress, Problems and Suggestions [J]. Journal of the Party School of the Central Committee of the CPC, 2017, 21(5): 113-121. 